\title{
eJRIEPS
}

Ejournal de la recherche sur l'intervention en éducation physique et sport

$24 \mid 2011$

Varia

\section{The place of knowledge in the representation of professional competence held by PE teachers}

Paula Maria Fazendeiro Batista, Amândio Braga dos Santos Graça and Zélia Maria Matos de Almeida Roque Pinto

\section{OpenEdition}

Journals

Electronic version

URL: http://journals.openedition.org/ejrieps/4027

DOI: 10.4000/ejrieps.4027

ISSN: 2105-0821

\section{Publisher}

ELLIADD

\section{Electronic reference}

Paula Maria Fazendeiro Batista, Amândio Braga dos Santos Graça and Zélia Maria Matos de Almeida Roque Pinto, «The place of knowledge in the representation of professional competence held by PE teachers », eJRIEPS [Online], 24 | 2011, Online since 01 July 2011, connection on 17 February 2020. URL : http://journals.openedition.org/ejrieps/4027 ; DOI : 10.4000/ejrieps.4027

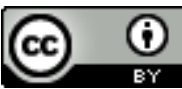

La revue eJRIEPS est mise à disposition selon les termes de la Creative Commons Attribution 4.0 International License. 
eJRIEPS 24 juillet 2011

The place of knowledge in the representation of professional competence held by PE teachers

Paula Maria Fazendeiro Batista, Amândio Braga dos Santos Graça, Zélia Maria Matos de Almeida Roque Pinto

Faculty of Sport, University of Porto, Laboratory: Sport Pedagogy, Portugal

\section{Abstract}

The purpose of this study was to locate the place of knowledge in the representation of professional competence held by PE teachers. We interviewed 30 PE teachers about their understanding of competence, using a semi-structured open-ended interview. Interpretative content analysis procedures were applied. The analytical framework based on nuclear categories defined in the Cheetham and Chivers' (1996, 1998) Model of Professional Competence: knowledge/cognitive competence; functional competence; personal/behavioural competence; values/ethical competence. Data showed that the ethical component was the most important. The subcategory specialized knowledge proved to be the most valued followed by tacit-practical knowledge and knowledge application.

Key Words: professional competence; knowledge base; teacher conceptions; Physical Education

\section{Introduction}

Despite multiple efforts aimed at clarifying the concept of competence, several areas of contamination remain. This leads not only to an indiscriminate use of the word competence by public definition, but also in its not so cautious, or even arbitrary use in the scientific discourse (Parente, 2003; Weinert, 1999). According to Weinert (2001, p.45), "it seems as if the concept of competence reveals a negative correlation between its popularity and its precision". In general it is possible to assume that there are three main positions in the conceptualization of competence: the observable performance or the outputs of the learning process (Boam \& Sparrow, 1992; Bowden \& Masters, 1993); the standard or quality of the outcome of a person's performance (Hager, 1994; Rutherford, 1995); and the underlying attributes of a person (Boyatzis, 1982; Sternberg \& Kolligian, 1990). 


\section{eJRIEPS 24 juillet 2011}

Besides these positions, other more integrative interpretations include the worker, the work and the context of work. Le Boterf (1994) considers that competence is situational, that is to say that it is exercised in a particular context, is mediated by constraints and resources, and suffers directly from the interferences of the situation. Moreover, the context in which each person works, the context of action (specific conditions, interactions with others), and personal experience cannot be separated from the interpretation that people have of the world around them (Velve, 2000).

According to Sandberg (2000), to describe competence requires taking, as a starting point, the conceptions of the workers and not just their attributes. From an interpretive perspective, in opposition to what happens from a rationalist perspective: "...competence is not seen as consisting of two separate entities, instead, the worker and work form one entity through the lived experience of work" (Sandberg, 2000, p. 11). Therefore competence includes (a) knowledge (which can be learned in the process of education), (b) experience (in the workplace and in social life), and the ability to use the knowledge and experience (Sandberg, 2001).

Despite all the attempts to unify these ideas, the notion of competence cannot be confined to a single theoretical construct, or limited to the selection of a better definition of the concept; various understandings remain in differentiated conceptual fields. Stoof, Martens, Merriënboer and Bastions (2002) sustain that the viability of the construction of the concept requires the presence of three key elements: people (who must contribute to the definition), goal (what is the purpose of the definition) and context (the context in which the definition will be used).

Despite its variability and inaccuracy, most authors agree that the concept of competence refers to an authentic combination of knowledge, skills and attitudes (e.g., Hager \& Gonzi, 1996; Mirabile, 1997; Parry, 1996; Stoof et al., 2002). Knowledge is usually described as a central element of competence, and knowledge base for teaching is seen as a complex framework that includes different types of knowledge that come from various fields, and are constructed upon different sources. Yet, in spite of the amount of the studies dedicated to teachers' knowledge and how it is acquired, there is no consensus as to the priority of the fields and the sources of knowledge (e.g., Hager \& Gonzi, 1996; Mirabile, 1997; Parry, 1996; Stoof et al., 2002).

The purpose of the present study was to examine PE teachers' conceptions about competence. More specifically, the following specific tasks were addressed: 


\section{eJRIEPS 24 juillet 2011}

- to discriminate the factors that PE teachers value in their conception of competence and situate the importance of knowledge among these nuclear components;

- to identify the types of knowledge PE teachers value in their conception of competence;

- to represent the "idea" of competence held by PE teachers.

\section{Methods}

\section{1. Sample}

The sample was composed of 30 PE teachers of both genders (16 men and 14 women). The age of participants and their working experience as PE teachers averaged respectively 39,03 years and 15,77 years. Twenty two of them were multiple job holders. Participation of all teachers in the study was voluntary.

\section{2. Data collection}

An interview protocol was built in order to identify the "idea of competence" held by PE teachers. The protocol adopted a semi-structured approach with six open-ended questions. This format was particularly useful to study the participants' beliefs, perceptions or accounts on a particular topic in detail. The semi-structured format was used in order to facilitate rapport and empathy, and to allow a greater flexibility of coverage and openness to the unexpected (Smith, 1995).

The interview script was evaluated by two senior researchers in sport pedagogy who have substantial experience with interview methods. A pilot study was conducted to evaluate the clarity, adequacy, and relevance of the interview questions for the target sample. Questions that composed the script are presented below in Table 1.

Table 1 - Interview script

Q1 - When you think about competence, what terms immediately come to your mind?

Q2 - What is for you a competent teacher?

Q3 - Which main features do you associate to a competent teacher?

Q4 - Which main features do you associate to an incompetent teacher?

Q5 - What are the requirements a teacher must meet to work competently within the profession?

Q6 - Think about teachers that you know or knew and select one (or more) that you consider a model(s) of a competent teacher. 


\section{eJRIEPS 24 juillet 2011}

After having explained the aim of the study, clarifying the conditions of participation, and obtaining the free and informed consent, each teacher was interviewed in a quiet and safe environment, without the interference of others. The interviews were recorded on audio tape and lasted between 25 and 90 minutes.

2. 3. Data analysis

The records of the interviews were transcribed verbatim and subsequently introduced in the qualitative data analysis software QSR Nvivo, version 7.0. Each teacher was identified with an alphanumeric code (e.g., PE1). Data were analysed using content analysis procedures. The analytical framework was built upon the Cheetham and Chivers' (1996, 1998) Model of Professional Competence. Figure 1 provides a detailed portrait of the categories of the main components of competence included in the model, namely a) knowledge/cognitive competence, b) functional competence, c) personal/behaviour competence, d) values/ethical competence, e) professional competence, f) reflection, and g) meta-competencies/trans-competencies. An extra category, appearance, which emerged from the data, was added to the list of the predefined components of competence. The physical and mental categories of the functional component were aggregated. The analysis was structured into two main stages: the first stage took on an iterative process of classification by using the predefined categories as the starting point. The second stage included two steps: (1) determining the frequency and relative frequency of each core component and its related components; (2) in-depth analysis of the data coded in each category and subcategory trying to map out the conception of competence conveyed by the participant PE teachers. 


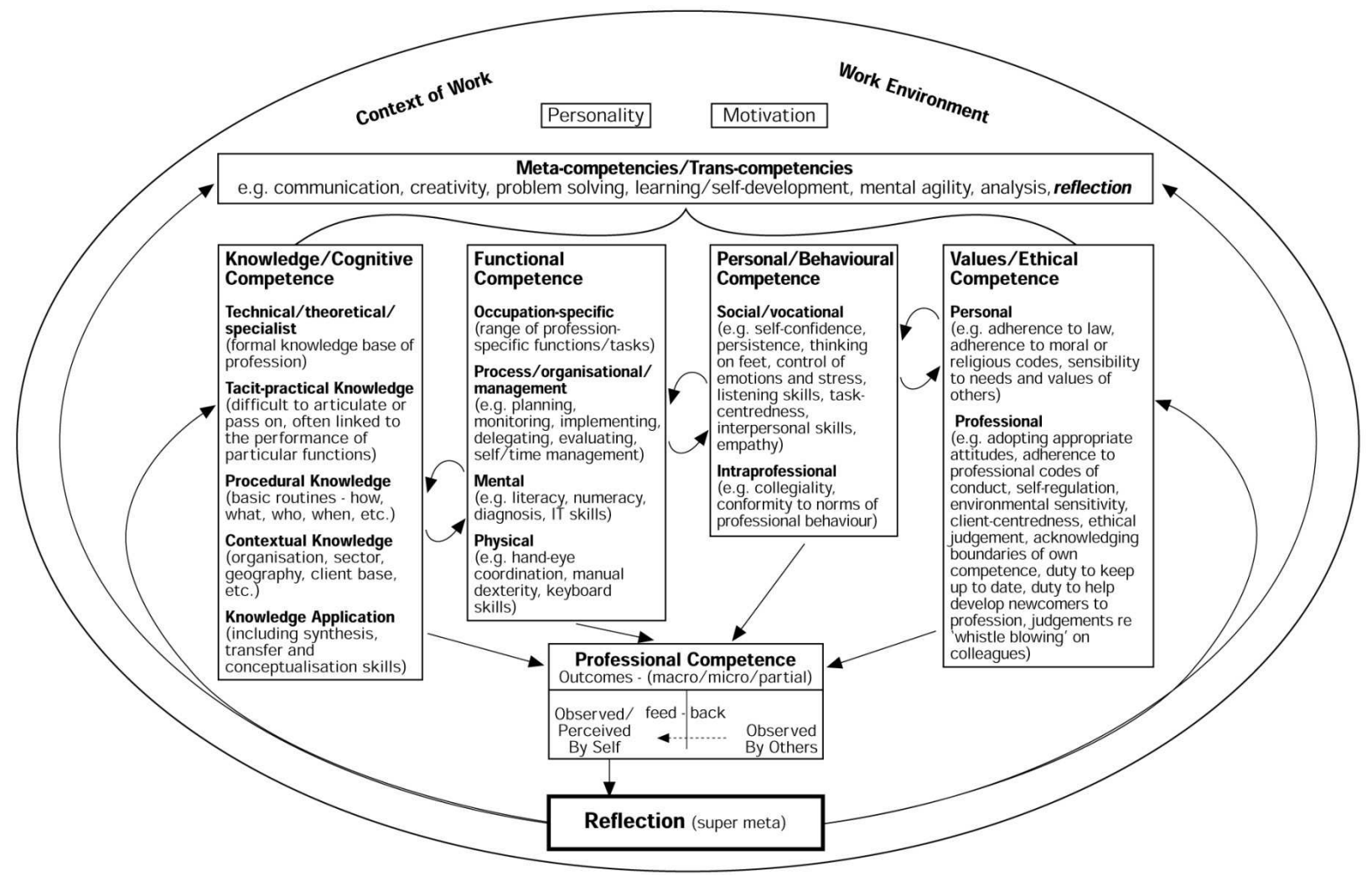

Figure 1. Model of professional competence (Cheetham \& Chivers, 1998, p.275) (Reprinted with the permission of the authors)

\section{4. Reliability}

Coding reliability was assured by assessing the inter observer and intra observer's agreement. Reliability tests included four interviews. Cohen's Kappa was calculated to eliminate the agreement by chance. The values for the agreement of two independent observers ranged from $85 \%$ to $90 \%$, and intra observer consistency ranged from $84 \%$ to $89 \%$. Since Fleiss (1981) considers an agreement greater than a score of $75 \%$ as strong, we concluded that our data were reliable enough to be used.

\section{Results}

Global Picture about competence

The discourse of PE teachers revealed a great diversity in relation to the notion of competence, ranging from a narrow and particularistic aspect, like "to know the space where is the class", to a broad and rather unspecific aspect. Several excerpts of teachers' interviews serve to illustrate that proposition: 


\section{eJRIEPS 24 juillet 2011}

\section{unspecific}

Responsibility; area of intervention, basically it's that. After comes_training, because it is almost unavoidable, since it is the fundamental step. I think like that! Training, responsibility; training and area of competence.." [PE5, paragraph 5]

Execution capability, being prepared to perform a specific function, a task, to execute that task; well being able to reach the goals that were set for a particular task, a particular activity, or a particular.... [PE19, paragraph 4]

\section{specific}

The quality of a teacher: to promote an activity aiming at pre-determined goals. Words I will say: goals, quality, teaching quality, learners' success, learners acquiring habits that are currently decreasing, because of sedentary habits, chiefly sedentary habits. [PE11, paragraph 9]

Regardless of the range of diversity among PE teachers' global concept of competence, the reference to the student was always present.

3. 1. Factors (nuclear components) that PE teachers value in their conception of competence

In relation to the importance attributed to each nuclear component, as we can see in Figure 2, the discourse of PE teachers was clearly marked by the ethical and cognitive components.

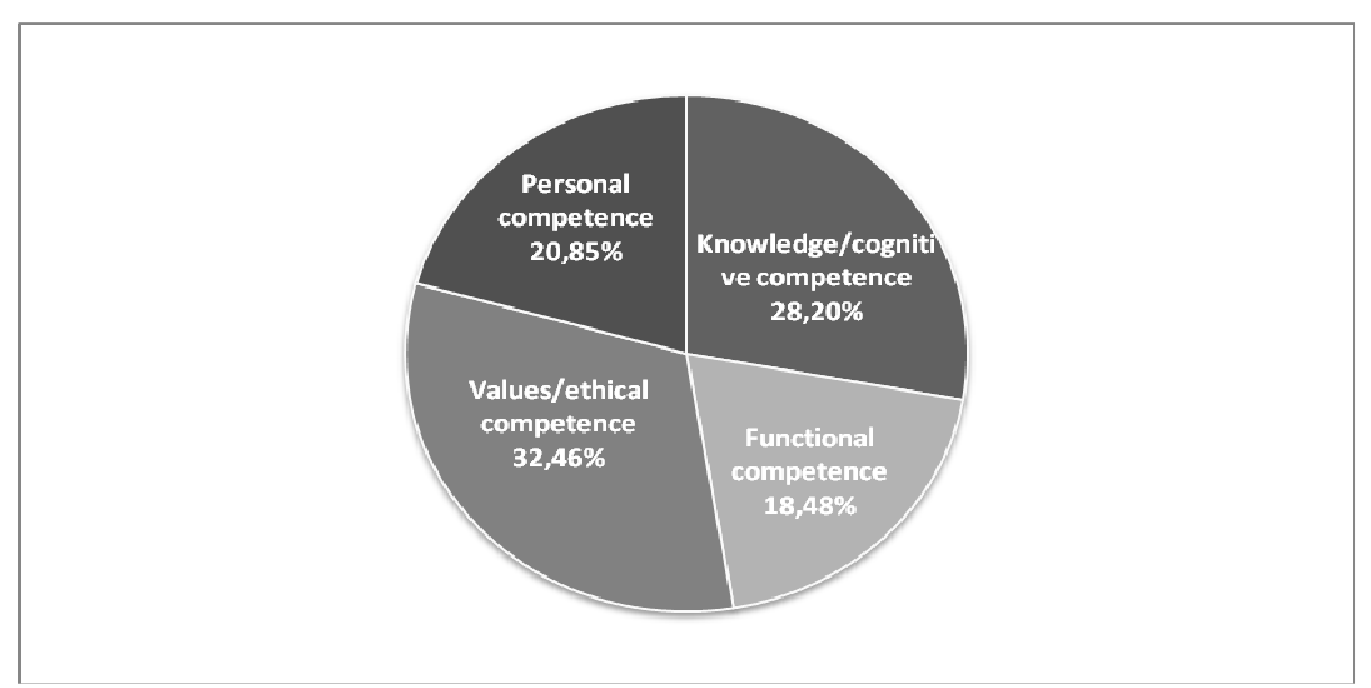

Figure 2. Relative distribution of core components of competence 


\section{eJRIEPS 24 juillet 2011}

Looking more closely at each component of competence, it was possible to see the relevance of each sub-category inside the nuclear components of competence (Table 1). Ethical competence emerged as the most relevant category, followed by knowledge. In contrast, the functional component was the least relevant.

Table 1. Cases and references by nuclear component of competence (categories) and related sub-categories.

\begin{tabular}{|c|c|c|c|}
\hline \multicolumn{4}{|c|}{ NUCLEAR COMPONENTS } \\
\hline categories and sub-categor & & cases & references \\
\hline \multirow{3}{*}{ Values/ethical competence } & personal & 18 & 32 \\
\hline & professional & 27 & 105 \\
\hline & Sub-total & & $137(32,46 \%)$ \\
\hline \multirow{6}{*}{$\begin{array}{l}\text { Knowledge/ } \\
\text { cognitive competence }\end{array}$} & technical/theoretical/specialist & 23 & 63 \\
\hline & tacit-practical & 13 & 18 \\
\hline & procedural & 9 & 11 \\
\hline & contextual & 6 & 9 \\
\hline & application & 12 & 18 \\
\hline & Sub-total & & $119(28,20 \%)$ \\
\hline \multirow{3}{*}{$\begin{array}{l}\text { Personal/behavioural } \\
\text { competence }\end{array}$} & Intra-professional & 8 & 15 \\
\hline & social/ vocational & 27 & 73 \\
\hline & Sub-total & & $88(20,85 \%)$ \\
\hline \multirow[t]{6}{*}{ Functional competence } & occupation-specific & 18 & 44 \\
\hline & process/organisational/management & 14 & 23 \\
\hline & mental & 5 & 6 \\
\hline & physical & 4 & 5 \\
\hline & Sub-total & & $78(18,48 \%)$ \\
\hline & & Total & 422 \\
\hline
\end{tabular}

\section{1. 1 Values/ethical component}

Regarding the ethical component, professional responsibility, understood as the accomplishment of professional routines (like punctuality and assiduity), was the aspect most often mentioned. Another salient aspect was the association of professionalism to values such as authenticity and honesty. The notion of moral authority, materialized in the transmission of values was present but only in the more experienced teachers.

I would begin by... first of all a competent teacher must be a responsible person. I think it is the most important, and developing this competence - being responsible encompasses everything - and students could see the teacher as a model; they could say something like: You know, this teacher requires me to be assiduous, to be punctual, but she is always the first to come into the classroom, she never arrives late, never after the second bell, pretending that she had not heard the bell ringing, because... [PE26, paragraph 25] 


\section{eJRIEPS 24 juillet 2011}

To be assiduous, punctual, active, always intervening; and being the students' friend $_{2}$ are just some of the ways of fostering a positive and constructive relationship with students; present, assiduous. [PE15, paragraph 19]

Good question! I think it is mainly professionalism, precision in what you do. You know? There are so many things that could be associated to professionalism: punctuality, assiduity, precision in what you do. [PE20, paragraph 6]

A characteristic is rigour, a person who is rigorous, who has well defined goals, who knows what he is doing, who is able, for instance, to pass on to students (I'm speaking of secondary school education), to justify what they are doing, and having this skill of making students aware of the critical points, knowing that to attain a certain level, to meet a certain goal they have to go through certain points that are crucial for the process. [PEMD9, paragraph 12]

Competence is being organized, being committed, and being reliable in what you do. In a word, being professional in a general way. [PE23, paragraph 5]

\section{1. 2. Knowledge/cognitive component}

Knowledge was seen as one of the requirements of competence. The theoretical/specialist knowledge, including academic and pedagogical knowledge, occupied a central place in professional preparation; however the non-linear relationship between theory and practice was also acknowledged. A clear difference between being a "good student" and being a "good teacher" emerged from the discourse.

... a lot of requirements in terms of knowledge, a proper academic education. [PE15, paragraph 18]

...to be a good university student does not mean to become a good teacher, but at least it is required to have a knowledgeable base. [PE30, paragraph 19]

The amount of references to tacit-practical knowledge and knowledge application assumed relative relevance especially among the experienced teachers. The roots of tacitpractical knowledge were mainly linked to personal and shared professional experiences, and less to practical sport experiences. The teachers interviewed for this study seemed to embrace the idea of practical rationality, which is revealed in the way they think about 


\section{eJRIEPS 24 juillet 2011}

knowledge application, i.e., knowledge has no direct application in practice. It is necessary to transform and to adjust one's knowledge in order to adapt to the comprehension level of the students, to the situation and task constraints. This idea of knowledge transformation was conveyed in expressions like how to adjust, how to adapt, how to guide.

The teacher who is able to transform a theoretical project into a project that works. [PE9, paragraph 9]

The teacher who is able to adjust, to make changes, without losing the common core of the teaching activity, you know. But, at the same time, the one who is able to effectively transmit knowledge and wisdom, to provide cues, desirably in a guide discovering way instead of a full pre-established way, you know? Fostering thinking, knowing... [PE9, paragraph 20]

A teacher who has extensive knowledge of the subject. Sometimes, rather than being an issue of subject matter knowledge, it is much more important to find out a way of getting students to know the contents for learning, of fine-tuning the level of objectives, or of making clear what is important for students to learn from that matter. [PE7, paragraph 12]

The number of quotations on the contextual and procedural knowledge was very limited. Among the references in these components, teachers with less experience produced more ideas about contextual knowledge, while the more experienced teachers quoted more often on procedural knowledge. Despite contextual knowledge being rarely mentioned, references to students were almost pervasive, either at the level of the individual student, or in relation to their social and family environments.

It is important to know that each student is a unique case; we should not treat students in a generic fashion. [PE25, paragraph 25]

She must know her students, she must make an effort to know her students as a previous concern, who they are, where they come from; be acquainted with their social context, try to understand the family factors that may be important to acknowledge and may interfere with students' learning. [PE8, paragraph 18]

The one who is sensitive to the specific characteristics of students and of the particular contexts they are embedded in; the one who is able to promote a certain kind of learning outcome. [PE1, paragraph 9] 
3. 1. 3. Personal/behavioural component

In general, the idea which was most prevalent was that teachers believe that interpersonal skills offer the basis for the teaching and learning process. These skills were translated into aspects that contribute to a good relationship between teacher and students including the ability to communicate, to talk with them. Commitment and persistence were also listed as key features. The pedagogical qualification of teachers was accentuated. References to pedagogy pervaded not only on personal and behavioural components, but also in others components of competence. We believe that the pedagogical component should not be seen as a subsidiary component but as an overarching component of competence.

...independently of the kind of relationship, no teacher could be competent if they doesn't have skills to establish a relationship with students, with school staff and with other teachers, relationship with peers, with parents, obviously with parents. [PEMD26, paragraph 18]

Good communicator, sensitive and knowledgeable. [PEFD12, paragraph 9]

At a different level of [...] but she is also able to transmit enthusiasm, yet in a different way I don't know how to put it in words, she has a great power to communicate with students, she masters perfectly the very contents, or subjects of the program...[PEMD2, paragraph 26]

To establish a good empathy with students, and with that empathy students are prone to view the teacher as an efficient educator. They will not say that their teacher is dull, and that they have no way to learn anything. [PEMD4, paragraph 12]

Essentially, good material resources, commitment also, because commitment jointly with good remuneration are the essential points, surely not everything, nevertheless well remunerated teachers will not need to look for other jobs in order to increase their wealth. [PEMB25, paragraph 19]

\section{1. 4. Functional component}

It was quite evident that teachers put emphasis in distinct aspects of the functional component of competence. While some teachers stressed the need to personalise 


\section{eJRIEPS 24 juillet 2011}

instruction and adjust subject matter to students, other teachers focused more on the need for a regular and systematic intervention. Others made remarks on the importance of mastering the newer technologies. Despite those differences, the enhancement of learning was the common thread that ran through most of the teachers' discourses, and so appeared as the fundamental purpose of their teaching. Most of the teachers pointed out the execution ability as a central aspect of the teacher activity. The execution ability was linked to action verbs, like to implement, to perform, to act, to accomplish, and so on.

Execution capacity, being prepared to perform a particular role, a particular task, executing that task well, to achieving the goals that were set for a particular task, or a particular activity. [PEMD19, paragraph 6]

Being able to act as required by the situation, that's the point, I think. [PEFD21, paragraph 23]

... and she must try to apply knowledge in the best way, being rigorous with the methods she uses, the procedures she adopts, to impart knowledge, to introduce concepts and to assign tasks that were needed. [PEMD3, paragraph 9]

One notorious result was the emphasis teachers put on knowing how to transmit, intimately related to knowing how to teach. Student learning appeared to be linked to the transmission of the subject matter. This link suggests that teachers understand the teaching process based on the process-product paradigm in which the students' learning gains are a direct result of teachers' behaviours in the instructional process. Teachers come to be understood as "engineers of education."

The association I make is that a good teacher is the one who knows how to teach, who knows how to be in a classroom, and the kids like to attend his classes. [PEFC30, paragraph 11]

Teaching the contents and enabling students to acquire more knowledge. [PEFC29, paragraph 19]

Well, the competent teacher must transmit contents, the essential contents; I don't know the exact word to convey this. [PEFB15, paragraph 6] 


\section{eJRIEPS 24 juillet 2011}

The competent teacher must be a person who can transmit the essential contents in a way that students acquire them [PEFB15, paragraph 15]

Knowing how to transmit knowledge is not enough. To be competent implies transmitting knowledge to someone and making it easy to acquire. [PEFD28, paragraph 22]

Lately, I'm revolving around a theme, we teachers should be teaching engineers. Therefore, we must have the ability to deal with 20 or more students in a class, and knowing that there are no two identical individuals, knowing that they could be sorted by levels, we must have the ability to reach all of them in some unique way. This is what I mean by a competent person, the one who is able to transmit, if not for all, for as many students as possible that one has to teach. [PEMD26, paragraph 11]

The notions of planning and evaluation are seen as necessary conditions in order to promote the success of students' learning. Planning and evaluation were the key factors of evidence for seeing teaching as a rational, purposeful, and systematic activity. The common purpose of all teaching was students' education, and the teaching process was considered to have a real value if it can be shown to be meaningful and relevant to the learning outcome. In this sense, the absence of planning was interpreted as a sign of incompetence.

Namely, lesson planning, thinking about the characteristics of his students and according to that organise his teaching process, in a way that the subsequent learning process can be effective, and so, preparing his teaching activity, adjusting his/her teaching interventions according to students learning. There is also a set of planning demands that makes a teacher a good professional. A person who improvises, that goes to class without preparing the lessons, cannot be a good teacher. [PEFD1, paragraph 21]

The teacher must prepare every lesson. And I speak for myself. Sometimes my experience allows me not to prepare a lesson, and it is always a big difference from a prepared lesson. A prepared lesson happens in a more smooth and effective way. [PEFC7, paragraph 18] 


\section{eJRIEPS 24 juillet 2011}

For me a competent teacher is a teacher, who prepares the classroom process; who has dignity in what he does. Because, I may eventually observe a lesson of a colleague and consider that I would teach it in another way, but as long as the colleagues have dignity in what they are doing, are prepared, engender a logically sequenced and developmental process, for me they are competent teachers. [PEMD9, paragraph 9]

\section{2. Other factors of competence}

In addition to the nuclear components of competence, the analytical framework contemplated other factors associated with competence. Among these factors, metacompetencies and motivation were the most valued in the PE teachers' conception of competence (Table 2).

Table 2. Other factors of competence

\begin{tabular}{llcc}
\hline categories & sub-categories & references/cases & $\begin{array}{c}\text { relative importance } \\
\text { for individual }\end{array}$ \\
\hline Context & work & $8 / 7$ & 1,14 \\
\cline { 2 - 4 } & environment & $8 / 5$ & 1,6 \\
\hline Meta-competencies & & $35 / 16$ & 2,19 \\
\hline Motivation & & $20 / 13$ & 1,54 \\
\hline Personality & & $14 / 10$ & 1,40 \\
\hline Perception of & hetero-perception & $18 / 10$ & 1,80 \\
\cline { 2 - 4 } competence & auto perception & $4 / 3$ & 1,33 \\
\hline Reflection & & $9 / 8$ & 1,13 \\
\hline Appearance & & $1 / 1$ & 1 \\
\hline
\end{tabular}

Looking into meta-competencies, the aspects most mentioned were the decision-making capacity, the adaptation capacity, as well as creativity. It is important to note that adaptability held a double meaning. This capacity was seen both as assimilation of the situational constraints to the teachers perspectives, and in the opposite direction, as accommodation of the teachers' views to the demands of the context and situational constraints. Assimilation and accommodation constitute the known phases of Piagetian adaptation; however we believe that these perspectives may also illustrate two different conceptions of the act of teaching. Teachers that emphasised assimilation put themselves at the centre of the instructional process, while teachers that emphasised accommodation placed the focus on the particularities of pedagogical situations.

Creativity and innovation associated with the need to acquire knowledge is also an idea that transpired from the teachers' discourses. 


\section{eJRIEPS 24 juillet 2011}

... basically, what I think that is fundamental is the adaptability, that is to be able, every day, to adapt ourselves to different situations, as, under the cultural point of view, also to adapt to the different changes that appear. Then also to adapt ourselves to the things that arise in terms of education... [PE5, paragraph 9]

... after he had a great creativity, he made a class with four tires, it was spectacular, and I do not know what, and he invented this and that ... He had creativity and imagination, and this marked me greatly. [PE10, paragraph 23]

Love and vocation were listed as prerequisites for being competent. Some teachers suggested that you cannot be competent if you don't love what you are doing; what's more, the same teacher said that understanding the emotional connection to work after many years in the field could only be understood with the existence of passion. The emotional connection appeared as an important manifestation of competence.

You must have passion for what you do, to like what you do; I cannot imagine a competent teacher if he doesn't like what he does, if he is not professional" [PEM10, paragraph 9]

To be interested; to like; really like the profession; first you go by choice and not because it was imposed on you. I think this is the essential starting point for anyone who hopes to have a successful career. [PE30, paragraph 19]

Despite the reduced number of remarks on reflection, teachers' statements were quite disparate. Some of them were confined to a single class, while other statements addressed broader social and educational issues, taking into account not only the immediate context but also the society as a whole. To some teachers, the challenge of social change appeared as a concern that could not be ignored.

Being competent is being reflexive; being thoughtful in what one does, and reformulating one's actions according to what you have and what comes to you, i.e. the students in an ever changing process within an increasingly diversified society, with values so different from ours. In order to deal with students that have such different views of life $e_{2}$ that come from such diversified social backgrounds, as we are getting now in schools $s_{2}$ it is important to think about these conditions, examine them, query them,..., you know. The simple transmission of knowledge is not sufficient to be competent. Being competent is being able to transmit knowledge to someone that is going to acquire it. [PE28, paragraph 22] 


\section{eJRIEPS 24 juillet 2011}

It is a person that works effectively through a guided discovery; and teaching people to search ways, or at least how to think if his way the correct path to follow is? This is a process of influence like others, but a process in which we are really active subjects... [PE28, paragraph 28]

The references to self-perception and hetero-perception of professional competence (how competent I perceive myself and how competent the others perceive me) made two ideas apparent: self-confidence connected to educational results, and the visibility of the educational results. In both cases, results confirm students' success.

Not only the one who is confident in what he is teaching, but also the one who has confidence in oneself. [PE4, paragraph 12]

A competent teacher is the one who makes teaching goals achievable and consequently brings out the best in his students. [PE8, paragraph 9]

This one speaks; that one tells and does, and has results to show. [PE26, paragraph 42]

But if you don't have a sound academic preparation, and particularly a pedagogical preparation, it will be very difficult for you to come in school and be effective. [PE18, paragraph 18]

3. 3. The "idea" of competence held by PE teachers.

The interpretation of the results suggests that the "idea" of competence held by PE teachers is based on issues of ethical, conceptual and relational nature, further consolidated by the influence of two strongly valued factors: the meta-competencies and motivation. In relation to the paradigmatic orientation underlying the notion of competence, while integrating different elements of the competence model used as reference for analysis, teacher behaviour and knowledge occupied the central place. The conception of competence held by teachers is associated with ability and knowledge. In this way, they are led to put the competence concept in an intermediate position between the rationalist and interpretive focus.

Data showed a composite of two perspectives: the functionalist and personalistic perspectives. Thus, it was possible to infer that the "idea" of competence was closer to 


\section{eJRIEPS 24 juillet 2011}

functionalism (worker-oriented or work-oriented approach) rather than structuralism (integrated approach to both worker and work). In Figure 3 we can observe the representation of the "idea" of competence held by PE teachers.

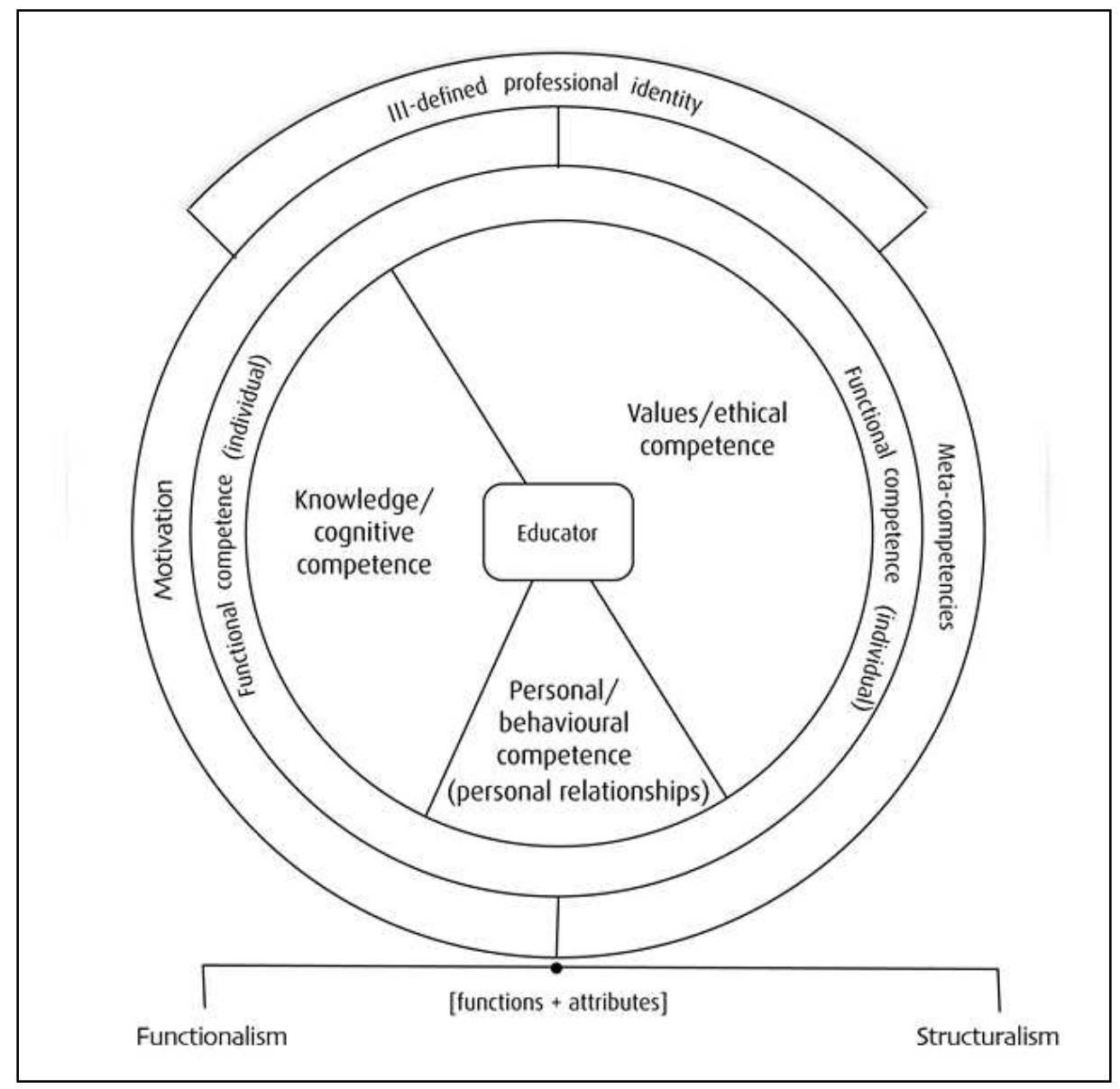

Figure 3. Representation of the "idea" of competence held by PE teachers

\section{Discussion}

The present study attempts to gain a better understanding of PE teachers' conceptions about the place of knowledge in relation to competence. Data showed that PE teachers have a poorly defined professional identity and give to knowledge and ethical issues a central role in professional competence. The ill-defined professional identity can be related to the fact that a majority (22/30) of PE teachers of this study have multiple jobs, and to the fact that their second job is related to fitness or coaching. But even if the sample was made up of teachers with a single job, the control of all the variables, to ensure uniformity, would almost be impossible. In the same line of thought, Feiman-Nemser and Floden (1986) state that the assumption of cultural uniformity of teaching is untenable. Teachers differ in age, experience, social and cultural background, gender, marital status, subject 


\section{eJRIEPS 24 juillet 2011}

matter wisdom, and ability. The schools in which they work also differ in many ways, as do the groups of students whom they teach. All these differences may lead to differences in teaching culture. (p. 507).

The ethical aspects appear to be associated with responsibility, understood as a routine accomplishment and professionalism, as is usually the case in different professions. Discourses were marked by the notion of value transmissions and by the necessity of teacher authority, i.e., an acceptable authority. This type of authority is designed by Estrela (1997) as moral authority. The author says “(...) being an educator requires a particular way of being a moral authority" (p.164).

Knowledge is perceived by most teachers as a key component of competence; similarly, different authors argue that knowledge play a central role to the activity of teaching. According to Graça (1999, p. 167) education is a complex activity which requires that teachers have expertise knowledge in several areas. Crum (2001) says that "the training within the educational content is definitely a key competence for PE teachers" (p.67).

The necessity to know subject matter appears closely linked to the ability to transmit it. These teachers report that it is not enough to simply have knowledge, but it is necessary to know how to transmit it. This idea is supported by Le Boterf (1984), for whom the ability to mobilize the knowledge that each one has is crucial. Among the referenced types of knowledge, the most relevant was the content domain and its transmission. These types of knowledge are referred to by Grossman (1990) as subject matter knowledge (knowledge of vocational education) and pedagogical content knowledge (how to make the subject matter content into forms more comprehensible for students). Shulman (1986) introduced the concept of pedagogical knowledge (PCK) as a distinctive body of knowledge for teaching.

Between the different kinds of knowledge, specialized knowledge, described as academic and teaching knowledge, occupies the central place. Tacit knowledge and application of knowledge was mentioned more by the experienced teachers. In relation to the application of knowledge, the discourse was positioned in practical rationality. Similarity (Schön (1983) believes that knowledge has no direct application in practice, it is necessary to change it, to adjust it in order to make it understandable to the students. Despite the marked differences between different types of knowledge, it cannot be said that one type of knowledge is more important than the other; each one play an important role. It is widely accepted that teachers' knowledge is an integrated system and it is very difficult to isolate each part. Parry (1996) states that different areas of knowledge have an interconnected 


\section{eJRIEPS 24 juillet 2011}

nature. Despite the importance of identifying the different types of knowledge, the attempt to distinguish different areas of knowledge tends to be arbitrary and artificial because they interact.

The idea of knowing how to be competent is largely expressed. Knowing how to plan, how to do and how to evaluate is mentioned with respect to a common goal: the success of students. This idea was already taken up in 1993 by Crum, when he claimed for initial training of PETE curricula based on the concept of teaching and learning.

Teachers' concentration on pedagogical issues was noticeable again in the personal component of competence. In general, the idea was that teachers think that the interpersonal relationships are the base for everything, so teachers must be empathic to students and maintain good relationships. It is necessary to have the capacity to communicate, to dialogue and to like being with people. Pedagogical issues cannot be seen as a subsidiary component of competence, but more as a fundamental component, and therefore must be integrated in all sectors of initial training.

Although the context factor was referred to by just a few teachers, those who mentioned it were fairly consistent. The need to contextualize the intervention was associated with the idea of how to improve educational performance. The ecology of the classroom advocated by Doyle (1990) thus takes form.

Strangely, only eight teachers valued reflection, despite literature indicating that this is a fundamental aspect of professional competence (Argyris \& Schön, 1974; Schön, 1984).

The factors perceived as the most important for competence were motivation and metacompetencies. The factors that motivate teachers to the profession are having the vocation and liking the profession. The capacity for adaptation and creativity was also seen as a fundamental aspect of the teachers' activity. Contextual factors, although rarely mentioned, point out that it's very important to know the students, either as part of a group, or as individuals, and to avoid the mistake of working with everyone in the same way. Teachers valued the results of their work, but the perception_of results by the others is more important than the self-perception.

\section{Conclusion}

The attempt to capture the place of knowledge in the representation of competence held by PE teachers put in evidence a set of data which is not always easy to interpret. Regardless of the impossibility of taking a straightforward reading of the data, it is possible to synthesise some aspects which were consistent through-out the analysis. The teachers 


\section{eJRIEPS 24 juillet 2011}

of this study revealed a great diversity of ways to express the notion of competence. Whatever the diversity, the central idea which that emerged was that the teacher is an educator and must therefore commit his/her actions to an ethical dimension. The need for pedagogical training was quite obvious in the teachers' statements, and was interpreted not only as a simple utilitarian element, but also as a key to competence that must to be integrated in teacher education.

Ethical and knowledge components of competence are the ones most valued by PE teachers. Interpersonal relationships, belonging to the personal component, are considered fundamental to the central activity of the teacher and the teaching-learning process.

Knowledge was referenced as one of the requirements of competence. The theoretical/specialist knowledge, embodied in academic and pedagogical knowledge, occupies the central place. However, all types of knowledge are important in the conception of competence held by PE teachers. In relation to the ethical component, the idea that the teacher must be guided, in his conduct, by ethical criteria is an idea that is well expressed.

Concerning the functional component, teachers also pointed out the ability to make it as a central aspect of the teacher activity. Aspects like planning, intervention and evaluation were mentioned in different ways: there was either an emphasis on the need to individualize and mould the subject matter or there was a focus on the need for a regular and systematic intervention.

In relation to the other factors of competence, the factors meta-competencies and motivation were the most valued. In meta-competencies the capacity for adaptation and creativity are listed as critical tools for professional practice because they allow teachers to deal with the unexpected that characterizes the teaching process. Liking the profession was viewed as the "engine" that triggers and maintains the development of competence.

Finally, the perspective of competence carried out is closer to functionalism (workeroriented or work-oriented approach) than to structuralism (integrated approach to both worker and work). Thus, in the assumption of competence, is not only the ability to obtain resources (competence as resources), but also to mobilize them in action (competence as integration of abilities).

It is then thought that to improve professional competence and the progressive integration of theory and practice (i.e., the goals and content of sport education programs) attention must be given to one's professional experience, ranging from poor perspectives to more 


\section{eJRIEPS 24 juillet 2011}

complete perspectives. We believe that the PE teacher education curriculum needs to explore new knowledge and ways of thinking, and this process must begin with the awareness of the education institutions to capture the perceptions of professionals about competence, trying to understand why and how their professional subjectivity has been constructed.

\section{References}

Argyris, C. \& Schön, D. (1974) Theory in practice: Increasing professional effectiveness. San Francisco: Jossey Bass.

Boam, R. \& Sparrow, P. (Ed.). (1992). Designing and achieving competency. London: McGraw-Hill.

Boyatzis R. E., (1982). The competent manager: A model for effective performance. New York: Wiler.

Bowden, J., \& Masters, G. (1993). Implications for higher education of a competencybased approach to education and training.Australia. Department of Employment, Education and Training. Evaluations and Investigations Program (EIP) Canberra: AGPS.

Cheetham, G., \& Chivers, G. (1996). Towards a holistic model of professional competence. Journal of European Industrial Training, 20, 20-30.

Cheetham, G., \& Chivers, G. (1998). The reflective (and competent) practitioner: A model of professional competence which seeks to harmonise the reflective practitioner and competence-based approaches. Journal of European Industrial Training, 22, 267-276

Crum, B. (1993). A crise da identidade da Educação Física. Ensinar ou não, eis a questão [The crisis of Physical Education Identity. To teach or not, that's the question]. Sociedade Portuguesa de Educação Física, 7, 133-148.

Crum, B. (2001). The "idola" of sport pedagogy researchers. Quest, 53, 184-191.

Doyle, W. (1990). Themes in teacher education research. In R. Houston, M. Haberman, \& J. Sikula (Eds.), Handbook of Research on teaching education (pp. 392-431). New York: McMillan.

Estrela, M. (1997). Viver e construir a profissão docente. [To live and construct the teacher profession] Porto: Porto Editora.

Feiman-Nemser, S. \& Floden, R. (1986). The cultures of teaching. In M. Wittrock (Eds.), Handbook of research on teaching (pp. 505-526). New York: Macmillan. 


\section{eJRIEPS 24 juillet 2011}

Fleiss, J. (1981). Statistical methods for rates and proportions. New York: Wiley.

Graça, A. (1999). Conhecimento do professor de Educação Física. In J. Bento (Eds.), Contextos da Pedagogia do Desporto. [Contexts of sport pedagogy] (pp. 168-251). Lisboa: Livros Horizonte.

Grossman, P. (Ed.). (1990). The making of a teacher: Teacher knowledge and teacher education. New York: Teachers College Press.

Hager, P. (1994). Is there a cogent philosophical argument against competency standards? Australian Journal of Education, 38, 3-18.

Hager, P. \& Gonczi, A. (1996). What is competence? Medical Teacher, 18, 15-18.

Le Boterf, G. (1994). De la compétence: essai sur un attracteur étrange [About competence: Essay on a strange attractor]. Paris: Les Éditions d'organisation.

Mirabile, R. J. (1997). Everything you wanted to know about competency modeling. Training and Development, 51(8), 73-77.

Parente, C. (2003). Construção social das competências profissionais: dois estudos de caso em empresas multinacionais do sector metalomecânico [Social construction of professional competences: Two case studies in multinational companies in the industrial sector]. Unpublished doctoral dissertation, Faculdade de Letras da Universidade do Porto, Porto.

Parry, S. (1996). The quest for competences: Competency studies can help you make HR decision, but the results are only as good as the study. Training, 33, 48-56.

Rutherford, P. (1995). Competency based assessment. Melbourne: Pitman.

Sandberg, J. (2000). Understanding human competence at work: An interpretative approach. Academy of Management Journal, 43, 9-25.

Sandberg, J. (2001). Understanding the basis for competence development. In C. Velde, (Ed.), International perspectives on competence in the workplace (pp.9-25). Dordrecht: Kluwer Academic Press.

Schön, D., (1983). The reflective practitioner: How professionals think in action. New York: Basic Books.

Schön, D., (1984). The reflective practitioner: How professionals think in action. New York: Basic Books.

Shulman, L. (1986). Those who understand: Knowledge growth in teaching. Educational Researcher, 15(2), 4-14. 


\section{eJRIEPS 24 juillet 2011}

Smith, J.A. (1995). Semi-structured interviewing and qualitative analysis. In: J. A. Smith, R. Harreé, \& L.V. Langenhove (Eds.), Rethinking methods in psychology (pp. 9-26). London: Sage Publications.

Sternberg, R. J. \& Kolligian, J. (1990). Competence considered. New Haven: Yale University Press.

Stoof, A, Martens, R., Merriënboer, J., \& Bastions, T. (2002). The boundary approach of competence: A constructivist aid for understanding and using the concept of competence. Human Resource Development Review, 1, 345-365.

Velve, C. (2000). An alternate conception of competence: Implications for vocational education and practice. Paper presented at the UTS research Centre Vocational Education \& Training Working Knowledge: Productive learning at work.

Weinert, F. (1999). Definitions and selection of competencies. Concepts of competence, 136. Munich: Max Planck Institute for Psychological Research.

Weinert, F.E., (2001). Concept of competence: A conceptual clarification. In D. S.Rychen \& L. H. Sagalnik, (Eds), Defining and selecting key competencies (pp. 45-66). Göttingen: Hogrefe \& Huber. 